\title{
Role of Gastric Colonization in Nosocomial Infections and Endotoxemia: A Prospective Study in Neurosurgical Patients on Mechanical Ventilation
}

\author{
Pierre Reusser, Werner Zimmerli, \\ Daniel Scheidegger, German A. Marbet, \\ Mauro Buser, and Klaus Gyr
}

\author{
From the Department of Internal Medicine, Surgical \\ Intensive Care Unit, Coagulation Laboratory, and Division \\ of Gastroenterology, University Hospital, Basel; University \\ Computer Center, Basel; and Department of Internal \\ Medicine, Kantonsspital, Liestal, Switzerland
}

\begin{abstract}
The role of gastric microbial colonization in nosocomial infections and endotoxemia was investigated prospectively in 40 neurosurgical patients requiring mechanical ventilation for $>48 \mathrm{~h}$. Each was studied up to $7 \mathrm{~d}$. Swabs from the nose and oropharynx were cultured at admission, and aspirates from the stomach and trachea were cultured daily until enteral alimentation was started. Patients were evaluated every second day for endotoxemia and coagulation activation. Of 153 gastric aspirates, $66.7 \%$ contained microorganisms at a mean quantity of $10^{7} \mathrm{cfu} / \mathrm{ml}$. Nosocomial pneumonia occurred in 15 patients, septicemia in 5 , and meningitis in 1 . The stomach was the evident source of infection in only 1 patient with pneumonia. Of 140 plasma samples, $12(8.6 \%)$ from 10 patients showed detectable endotoxin levels, but there was no association between endotoxemia or coagulation activation and the presence of microorganisms in the stomach. The stomach was not an important source for nosocomial infections or endotoxemia, even in patients with high gastric $\mathrm{pH}$.
\end{abstract}

Patients admitted to an intensive care unit (ICU) are often treated prophylactically with histamine-2 $\left(\mathrm{H}_{2}\right)$ receptor blockers or antacids to reduce the risk of gastroduodenal stress ulcers and bleeding [1, 2]. The rise of gastric $\mathrm{pH}$ induced by such treatment promotes microbial colonization of the stomach [3-8]. Gastric microbial growth may predispose to tracheal colonization in intubated patients $[5,8-10]$, and possibly increase the risk for nosocomial pneumonia. Three recent studies of ICU patients receiving mechanical ventilation showed an association between nosocomial pneumonia and treatment with

Received for publication 1 November 1988 and in revised form 24 April 1989.

This work was presented in part at the Interscience Conference on Antimicrobial Agents and Chemotherapy, October 1988, Los Angeles.

Informed consent was obtained from the patients or their legal guardians. The study followed the guidelines of the Ethical Committee of Basel University Hospital.

Dr. W. Zimmerli is the recipient of a career development award of the Swiss National Science Foundation.

The authors thank the staff and nurses of the surgical intensive care unit and the laboratory personnel of the Microbiology and Coagulation Laboratories of Basel University Hospital for cooperation and assistance and Mary Wieckowicz for editorial review.

Please address requests for reprints to Dr. Pierre Reusser. Present address: Division of Oncology, University Hospital, CH-1011 Lausanne, Switzerland.
$\mathrm{H}_{2}$-receptor blockers or antacids, but whether the stomach was a source of the pathogens causing pneumonia was not evaluated $[7,11,12]$.

Moreover, in ICU patients with compromised gastric mucosal barrier, colonization of the stomach might also contribute to the occurrence of coagulation activation, endotoxemia, or septicemia resulting from passage of microbial components or microorganisms into the blood [4].

We prospectively studied neurosurgical ICU patients to assess the effect of elevated gastric $\mathrm{pH}$ on gastric colonization and to determine whether the colonized stomach was the source of subsequent nosocomial infections. All patients were on prolonged mechanical ventilation and were studied for the first week after admission to the ICU. Patients were also evaluated for endotoxemia and coagulation activation to identify a possible systemic effect of gastric colonization.

\section{Patients and Methods}

The investigation was conducted prospectively in the surgical ICU of Basel University Hospital from August 1984 to September 1986 among patients enrolled in a randomized controlled trial of ranitidine hydrochloride and antacids for prevention of gastroduodenal stress lesions [13]. Patients were selected for that trial if they had undergone cranial neurosurgery 
for severe trauma or bleeding, and if their neurologic condition indicated the need for $>48 \mathrm{~h}$ of mechanical ventilation after surgery. Ineligibility criteria were age $<15 \mathrm{y}$, a history of gastroduodenal surgery or ulcer disease, current antiulcer treatment, or overt gastrointestinal bleeding.

Of 248 neurosurgical patients admitted to the ICU over the defined time period, 97 met the study criteria. Of these $97,40(41 \%)$ completed the trial. The rest were excluded by omission of the house staff or unobtainable early consent (26 cases), if gastroduodenoscopy was not performed as required by the protocol [13] or revealed preexisting ulcer disease ( 21 cases), or if mechanical ventilation was required $\leqslant 48 \mathrm{~h}$ ( 10 cases). Additional exclusion criteria were ongoing infection or therapeutic antibiotic treatment on admission; however, no patient was excluded for these reasons. Patients were enrolled within $12 \mathrm{~h}$ of admission to the ICU and were followed for $\leqslant 7 \mathrm{~d}$ if they remained intubated and ventilated. Infections occurring within $48 \mathrm{~h}$ of extubation were included in the analysis.

The 40 evaluable patients had a median age of $34 \mathrm{y}$ (range 15-76); 10 were female and 30 were male. Thirty-seven had severe head injury, associated with multiple trauma in seven cases, and three had spontaneous intracranial hemorrhage. Neurosurgery consisted of a craniotomy in 27 patients; an intracranial pressure monitoring device was inserted in the other 13 patients. Twenty-six patients $(65 \%)$ with multiple trauma or proven or suspected basilar skull fracture received parenteral isoxazolyl penicillins or trimethoprim/sulfamethoxazole as perioperative prophylaxis. This treatment was started immediately before surgery and discontinued $24 \mathrm{~h}$ later. Every patient received mechanical ventilation via an orotracheal tube and had a nasogastric tube in place. Thirty-four patients remained intubated and ventilated $\geqslant 7 \mathrm{~d}$. Three patients were extubated on day 4 , two on day 5 , and one on day 6 . Nineteen randomly chosen patients received stress ulcer prophylaxis with ranitidine and antacids to maintain gastric $\mathrm{pH} \geqslant 4$; the other 21 patients received no prophylaxis [13].

The following data were recorded for each patient daily: highest and lowest values of rectal temperature and blood pressure; white blood cell count (WBC) with differential counts; creatinine clearance; and use of antibiotics, $\mathrm{H}_{2}$-receptor blockers, antacids, and vasopressor agents. An anteroposterior chest radiograph was obtained at admission and then at least every second day.
Microbiologic studies. Upper airway colonization was assessed by collecting swabs from the nose and oropharynx plus tracheal aspirates at admission and by obtaining other tracheal aspirates daily as long as gastric aspirates were cultured. Tracheal aspirates were obtained aseptically by suctioning secretions with a catheter through the orotracheal tube directly into a sterile secretion trap.

To determine the effect of stress ulcer prophylaxis on gastric colonization, aspirates from the nasogastric tube were obtained daily until enteral alimentation was started (median onset, day 5; range, days 4-7). Gastric juice was aspirated into a sterile vial after the first $5-10 \mathrm{ml}$ was discarded. An additional aspirate was used to measure the $\mathrm{pH}$ by indicator paper (E. Merck, Darmstadt, FRG).

Blood cultures were obtained by venipuncture if septicemia was suspected, or if patients had unexplained fever $>38^{\circ} \mathrm{C}$ with a WBC above $10 \times 10^{\%} / 1$ plus shift of neutrophils to immature forms. Any other suspected focus of infection was also cultured.

All clinical specimens were processed and cultured in the microbiology laboratory of Basel University Hospital using standard techniques. Staphylococcus aureus strains were further identified by phage typing. When a bacterial pathogen was isolated, the susceptibility pattern to a standard range of antimicrobial agents was determined by minimal inhibitory concentration micromethod [14]. Microorganisms in gastric aspirates were quantified to correlate the counts with gastric $\mathrm{pH}$. Tenfold serial dilutions of gastric aspirates were made in isotonic phosphatebuffered saline, and aliquots of the dilutions from $10^{-3}$ to $10^{-6}$ were plated on sheep blood agar, MacConkey's and Sabouraud's agars for aerobic cultures, plus on supplemented trypticase soy agar, neomycin agar, and kanamycin-vancomycin blood agar for anaerobic cultures. The plates were incubated at $35^{\circ} \mathrm{C}$. Aerobic bacteria were counted after $24 \mathrm{~h}$ in culture, anaerobes and yeasts after $48 \mathrm{~h}$. The resulting counts were expressed as $\log _{10}$ colony-forming units (cfu)/ml of gastric juice.

Definition of colonization and infection. The pattern of colonization was examined by comparing microbial strains of the same species cultured from two or more sites. Bacterial strains of the same species were considered identical when the antimicrobial susceptibility pattern, plus the phage type for $S$. aureus, was concordant. In case of concordance, a time sequence of strain isolation from different sites was assumed to indicate the direction of 
colonization. For a given microorganism, only the first identifiable transmission sequence was considered.

Tracheal colonization was defined as recovery of a pathogen in the absence of signs of pneumonia. Pneumonia was diagnosed when isolation of a pathogen from tracheal aspirates occurred in combination with $>25$ granulocytes and $<10$ squamous epithelial cells per low-power field on Gram's stain that was associated with fever $>38^{\circ} \mathrm{C}$, WBC $>10 \times 10^{\circ} / 1$ with shift of neutrophils to immature forms, and a new alveolar infiltrate on chest radiograph that persisted $\geqslant 2 \mathrm{~d}$. Diagnosis of septicemia was based on positive blood cultures plus systemic signs of infection (fever $>38^{\circ} \mathrm{C}$ and WBC $>10 \times 10^{\circ} / 1 \mathrm{com}$ bined with either hypotension requiring vasopressor agents, renal failure, or disseminated intravascular coagulation [DIC]). The presence of these conditions or of signs of other infections was assessed independently by two investigators (P. R. and W. Z.); a third opinion was obtained in cases of disagreement.

Endotoxin and coagulation tests. The presence of plasma endotoxin and of coagulation activation was assessed at admission and then every second day. For the endotoxin test, $10 \mathrm{ml}$ of blood was collected by venipuncture in pyrogen-free tubes (Vacutainer; Beckton-Dickinson, Rutherford, NJ), to which $250 \mathrm{USP}$ units of pyrogen-free heparin $(\mathrm{Li}$ quemin; Hoffmann-La Roche, Basel, Switzerland) had been added. The sample was processed to platelet-rich plasma by centrifugation at $200 \mathrm{~g}$ for $10 \mathrm{~min}$ at $4^{\circ} \mathrm{C}$. To remove endotoxin inhibitors, the plasma was diluted 1:10 in distilled, sterile, pyrogenfree water and heated at $75^{\circ} \mathrm{C}$ for $5 \mathrm{~min}$ according to the method of Harris et al. [15]. The sample was then stored in aliquots at $-70^{\circ} \mathrm{C}$ until further testing, as long-term storage is not associated with loss of endotoxin activity [15]. The assay was accomplished by using the chromogenic substrate $S 2423$ (Kabi Diagnostica, Stockholm), and a result of $\geqslant 10$ $\mathrm{pg} / \mathrm{ml}$ was considered positive [15].

Fibrinogen, platelet counts, fibrin(ogen) degradation products, ethanol gelation, reptilase time, and factor $\mathrm{V}$ were measured to provide a semiquantitative score for DIC. Simultaneously, plasma prekallikrein (PK) and antithrombin III (AT-III) were measured. The methods to determine these parameters and to calculate the DIC score have been described [16]. DIC score were 0-13; 13 was the most severe DIC.
Statistical analyses. The method of Buser et al. [17] was used to evaluate the statistical association of identical strains of aerobic gram-negative bacilli or gram-positive cocci cultured from two sites. Every organism that could potentially be isolated was assigned to a precise position on both an $\mathrm{x}$ - and $\mathrm{y}$-axis delimiting a square area, the axes representing clinical specimens from two different culture sites (e.g., $\mathrm{x}$-axis, gastric aspirate; $\mathrm{y}$-axis, tracheal aspirate). When organisms were cultured from both specimens, each association between two organisms from different sites determined a position on the square area. Identical strains at both sites defined positions in a diagonal cluster between the two axes. The probability that this diagonal clustering was significantly different from a random distribution or from other clusters was assessed by $\chi^{2}$ test with Yates' correction or, if necessary, by the coefficient of dispersion test [17].

Analysis of other data was done using the Spearman rank correlation coefficient test for continuous variables and Fisher's exact test for dichotomous variables. $\mathbf{P}<.05$ was considered significant.

\section{Results}

Microbiological results. The type and frequency of aerobic gram-negative bacilli, gram-positive cocci, and yeasts isolated from gastric and tracheal aspirates are shown in table 1.

Two-thirds (102) of 153 gastric aspirates contained microorganisms. In these 102 aspirates, gram-negative bacilli were found in $\mathbf{2 2 \%}$, gram-positive cocci in $57 \%$, anaerobic bacteria in $30 \%$, and yeasts in $64 \%$. The average quantity of microorganisms in each of these subgroups was between $10^{6}$ and $10^{8}$ $\mathrm{cfu} / \mathrm{ml}$ throughout the sampling period. Gramnegative enteric bacilli were recovered from gastric aspirates of $11(27.5 \%)$ of the 40 patients.

There was a positive correlation between gastric $\mathrm{pH}$ and $\log$ concentration of gram-negative bacilli $\left(r_{\mathrm{s}}=.300, P=.0001\right)$, gram-positive cocci $\left(r_{\mathrm{s}}=\right.$ $.675, P<.00001)$, anaerobes $\left(r_{\mathrm{s}}=.501, P<.00001\right)$, and yeasts $\left(r_{\mathrm{s}}=.252, P=.0008\right)$. Ninety-five percent of gram-negative bacilli, $93 \%$ of gram-positive cocci, $97 \%$ of anaerobes, and $58 \%$ of yeasts were recovered from gastric aspirates with $\mathrm{pH} \geqslant 4$.

Gastric aspirates in the same $\mathrm{pH}$ range $(\mathrm{pH} \geqslant 4$ or $<4$ ) were compared between patients receiving stress ulcer prophylaxis and patients without such treatment. There was no difference in quantity or 
Table 1. Aerobic gram-negative bacilli, gram-positive cocci, and yeasts isolated from gastric and tracheal aspirates of 40 neurosurgical intensive care unit patients receiving mechanical ventilation.

\begin{tabular}{|c|c|c|c|c|c|}
\hline \multicolumn{3}{|c|}{ Gastric aspirate $(n=153)$} & \multicolumn{3}{|c|}{ Tracheal aspirate $(n=157)$} \\
\hline Microorganism & $\begin{array}{l}\text { No. of samples } \\
\text { with growth }\end{array}$ & $\begin{array}{l}\text { No. of patients } \\
\text { culture-positive }\end{array}$ & Microorganism & $\begin{array}{l}\text { No. of samples } \\
\text { with growth }\end{array}$ & $\begin{array}{l}\text { No. of patients } \\
\text { culture-positive }\end{array}$ \\
\hline \multicolumn{6}{|l|}{ Gram-negative bacilli } \\
\hline Escherichia coli & 10 & 4 & Hemophilus influenzae & 76 & 30 \\
\hline Enterobacter cloacae & 3 & 2 & Enterobacteriaceae & 18 & 14 \\
\hline Klebsiella species & 3 & 2 & E. coli & 12 & 4 \\
\hline H. influenzae & 3 & 3 & Pseudomonas aeruginosa & 6 & 4 \\
\hline Proteus vulgaris & 2 & 1 & Proteus mirabilis & 5 & 2 \\
\hline Pr. mirabilis & 2 & 2 & Acinetobacter species & 4 & 3 \\
\hline Enterobacteriaceae & 2 & 2 & En. cloacae & 3 & 3 \\
\hline \multirow[t]{2}{*}{ Proteus rettgeri } & 1 & 1 & Klebsiella species & 3 & 3 \\
\hline & & & Serratia species & 1 & 1 \\
\hline \multicolumn{6}{|l|}{ Gram-positive cocci } \\
\hline Streptococcus species & 59 & 28 & Streptococcus species & 78 & 33 \\
\hline \multirow[t]{2}{*}{ Staphylococcus aureus } & 5 & 3 & S. aureus & 53 & 19 \\
\hline & & & $\begin{array}{l}\text { Coagulase-negative } \\
\text { staphylococci }\end{array}$ & 10 & 7 \\
\hline \multicolumn{6}{|l|}{ Yeasts } \\
\hline Candida species & 65 & 24 & Candida species & 15 & 10 \\
\hline
\end{tabular}

pattern of microbial growth, indicating that $\mathrm{pH}$ was the determining factor for microbial growth rather than other drug effects.

The frequency and sequence of isolation of identical bacterial strains cultured from different sites is shown in table 2. There was a significant association of identical strains of gram-negative bacilli or gram-positive cocci isolated from both the stomach and the trachea, but no consistent direction of transmission that implicated the stomach as an impor-

Table 2. Identical bacterial strains* recovered from different culture sites and sequence of isolation in the $\mathbf{4 0}$ study patients.

\begin{tabular}{|c|c|c|c|c|c|}
\hline \multirow[b]{2}{*}{ Sites A/B } & \multirow{2}{*}{$\begin{array}{c}\text { No. patients } \\
\text { with identical } \\
\text { strains at } \\
\text { sites } A+B\end{array}$} & \multirow[b]{2}{*}{$P^{\dagger}$} & \multicolumn{3}{|c|}{ Sequence of isolation } \\
\hline & & & $\begin{array}{c}\text { First at } \\
\text { site A }\end{array}$ & $\begin{array}{l}\text { First at } \\
\text { site B }\end{array}$ & $\begin{array}{c}\text { At sites A/B } \\
\text { simultaneously }\end{array}$ \\
\hline \multicolumn{6}{|l|}{ Gram-negative bacilli } \\
\hline Nose/stomach & 3 & ns & 1 & $\ddagger$ & 2 \\
\hline Oropharynx/stomach & 4 & ns & 2 & $\ddagger$ & 2 \\
\hline Stomach/trachea & 10 & .001 & 3 & 4 & 3 \\
\hline Nose/trachea & 4 & $<.001$ & 3 & $\ddagger$ & 1 \\
\hline Oropharynx/trachea & 4 & $<.001$ & 3 & $\ddagger$ & 1 \\
\hline \multicolumn{6}{|l|}{ Gram-positive cocci } \\
\hline Nose/stomach & 7 & ns & 4 & $\ddagger$ & 3 \\
\hline Oropharynx/stomach & 11 & .005 & 8 & $\ddagger$ & 3 \\
\hline Stomach/trachea & 28 & $<.001$ & 7 & 12 & 9 \\
\hline Nose/trachea & 18 & $<.001$ & 6 & $\ddagger$ & 12 \\
\hline Oropharynx/trachea & 17 & $<.001$ & 8 & $\ddagger$ & 9 \\
\hline
\end{tabular}

* Strains of the same bacterial species considered identical when antimicrobial susceptibility pattern (plus phage type in case of Staphylococcus aureus) was concordant.

$\dagger$ The statistical association of identical bacterial strains at two sites was evaluated by the method of Buser et al. [17]. ns indicates $P \geqslant .05$.

$\mp$ Because swabs from the nose and from the oropharynx were systematically collected only at study onset, these transmission sequences were not evaluable. 
Table 3. Nosocomial infections occurring among the 40 study patients during the first week of mechanical ventilation or within $48 \mathrm{~h}$ of extubation.

\begin{tabular}{lccccc}
\hline & Rate, * & $\begin{array}{c}\text { Median day } \\
\text { of onset } \\
\text { (range) }\end{array}$ & $\begin{array}{c}\text { Case } \\
\text { fatality, } \\
\text { no. }\end{array}$ & $\begin{array}{c}\text { Treatment } \\
\text { with } \\
\text { ranitidine, } \\
\text { no. }\end{array}$ & $\begin{array}{c}\text { Perioperative } \\
\text { antibiotic } \\
\text { prophylaxis, } \\
\text { no. }\end{array}$ \\
\hline $\begin{array}{l}\text { Pneumonia } \\
\text { Meningitis }\end{array}$ & $15(37.5)$ & $4(2-9)$ & 2 & 7 & 10 \\
$\begin{array}{l}\text { Septicemia } \\
\text { Infection without } \\
\text { identifiable sourcet }\end{array}$ & $3(2.5)$ & 5 & 1 & 0 & 1 \\
$\begin{array}{l}\text { No infection during } \\
\text { study period }\end{array}$ & $18(12.5)$ & $6(5-7)$ & 0 & 1 & 4 \\
\hline
\end{tabular}

NOTE. Treatment with ranitidine was with or without antacids.

* Two patients developed both pneumonia and septicemia. No other patient had more than one type of infection during the study period.

$\dagger$ Systemic signs of infection as defined in the absence of an identifiable focus of infection.

tant source of tracheal colonization. In three patients, gram-negative bacilli were detected in the stomach before isolation from the trachea. However, in two of the three cases the organisms were simultaneously recovered from other sites (Klebsiella pneumoniae in the nose; Proteus mirabilis in the oropharynx). Only in one patient was the organism (Escherichia coli) initially isolated exclusively from the stomach, indicating that tracheal colonization may have originated from the gastrointestinal tract. The patient developed subsequent pneumonia caused by this organism.

Nosocomial infections. Nosocomial infections during the defined observation period are shown in table 3. The two deaths from pneumonia (one caused by $S$. aureus/Hemophilus influenzae, the other by Pseudomonas aeruginosa) occurred on days 24 and 26 after admission to the ICU. One patient with a cerebrospinal fluid leak developed signs of bacterial meningitis and died on day 20. A causative pathogen was not identified.

There were no significant differences in the rates of either pneumonia or septicemia between patients with and without stress ulcer prophylaxis.

The organisms most frequently associated with pneumonia were $H$. influenzae (seven cases), S. aureus (six cases), and Streptococcus pneumoniae (three cases; table 4). Most of the bacterial strains that caused pneumonia were first detected in tracheal aspirates. Septicemia was caused by $S$. aureus in four of five cases; in three cases this organism was also recovered from the tip of an intravenous catheter.
Table 4. Microorganisms associated with pneumonia and septicemia in 40 study patients.

\begin{tabular}{|c|c|c|}
\hline Microorganisms & $\begin{array}{c}\text { No. } \\
\text { of cases }\end{array}$ & $\begin{array}{c}\text { Sites of } \\
\text { first isolation }\end{array}$ \\
\hline \multicolumn{3}{|l|}{ Pneumonia* } \\
\hline \multicolumn{3}{|l|}{ Staphylococcus aureus } \\
\hline Hemophilus influenzae & 3 & Tracheal aspirate \\
\hline S. aureus & 2 & $\begin{array}{l}\text { Tracheal aspirate, } \\
\text { blood }\end{array}$ \\
\hline \multicolumn{3}{|l|}{ H. influenzae/ } \\
\hline pneumoniae & 2 & Tracheal aspirate \\
\hline \multicolumn{3}{|l|}{$H$. influenzael } \\
\hline S. aureus & 1 & Tracheal aspirate \\
\hline \multicolumn{3}{|l|}{$\begin{array}{l}\text { H. influenzae, } \\
\text { secondary Pseudo- }\end{array}$} \\
\hline E. coli & 2 & $\begin{array}{l}\text { Gastric juice, } \\
\text { oropharynx/ } \\
\text { tracheal aspirate }\end{array}$ \\
\hline Acinetobacter & 1 & Tracheal aspirate \\
\hline Klebsiella pneumoniae & 1 & $\begin{array}{l}\text { Nose/tracheal } \\
\text { aspirate }\end{array}$ \\
\hline$P$. aeruginosa & 1 & Tracheal aspirate \\
\hline Undefinable (mixed flora) & 1 & - \\
\hline \multicolumn{3}{|l|}{ Septicemia } \\
\hline S. aureus & 4 & $\begin{array}{l}\text { Nose, tracheal } \\
\text { aspirate; nose/ } \\
\text { oropharynx/ } \\
\text { tracheal aspirate; } \\
\text { wound }\end{array}$ \\
\hline E. coli & 1 & $\begin{array}{l}\text { Oropharynx/ } \\
\text { tracheal aspirate }\end{array}$ \\
\hline
\end{tabular}

* All cultured pathogens potentially involved in causing pneumonia are listed in their respective combination. 
Plasma endotoxin and coagulation studies. Of 140 plasma samples, $12(8.6 \%)$ from 10 patients had detectable endotoxin concentrations at a median of $26.2 \mathrm{pg} / \mathrm{ml}$ (range, 15.9 to $>100$ ). Table 5 summarizes the coagulation studies. In both a time-independent and a time-dependent analysis, there was no statistical association between the occurrence of gastric aspirates containing $>10^{6} \mathrm{cfu} / \mathrm{ml}$ of gramnegative bacilli, gram-positive cocci, anaerobes, or yeasts and either endotoxemia or changes in any of the coagulation parameters.

\section{Discussion}

The results of this study confirm that intragastric microbial growth is pH-dependent [18-20] and promoted by treatment with $\mathrm{H}_{2}$-receptor blockers or antacids [3-8]. However, our data do not support results from previous studies on intubated ICU patients, which suggested that gastric colonization was a significant risk factor for subsequent tracheal colonization or pneumonia [5, 8-10].

Two-thirds of gastric aspirates collected during the study contained microorganisms, and 11 patients $(27.5 \%)$ had gram-negative enteric bacilli cultured from the stomach. Moreover, 10 patients had identical strains of gram-negative bacilli in gastric and tracheal aspirates, but the stomach appeared to be the exclusive source of tracheal colonization and pneumonia in only one case.

Most of the bacterial strains causing pneumonia in this study were first detected in tracheal aspirates. It has been clearly demonstrated that the oropharynx can be a significant source of tracheal colonization and pneumonia for $S$. aureus [21], $H$. influenzae [22], or gram-negative bacilli [23] in intubated patients.
Since tracheal colonization rarely results from contaminated respiratory assistance devices [24], the microorganisms most often penetrate the trachea during intubation [21] or thereafter when the endotracheal tube alters or bypasses local defense mechanisms [23, 25]. The patients were already intubated when they were enrolled in our study. Therefore, the nasooropharynx could have been an important source of the microorganisms cultured from tracheal aspirates that caused pneumonia. This is supported by the fact that bacterial strains recovered from the nose or from the oropharynx at study onset were significantly correlated with identical strains isolated from tracheal aspirates.

Previous reports suggest that the stomach is an additional source of organisms colonizing the trachea in intubated patients with high gastric $\mathrm{pH}[5$, 8-10]. Six of 10 patients on mechanical ventilation reported by Atherton and White [10] had identical gastric and tracheal bacteria, and in three of these the organism was found in the stomach at least $1 \mathrm{~d}$ earlier than in the trachea. Of 60 patients studied by du Moulin et al. [5] in a respiratory ICU, 17 had a definable sequence of microbial transmission between stomach and trachea; in 11 cases the microorganism was first isolated from the stomach. In a more recent study of 142 patients receiving acid-reducing stress ulcer prophylaxis, 45 patients had an organism in the stomach that was also isolated from the trachea 1-2 d later [8]. However, none of the three reports mentioned oropharyngeal culturing, so the oropharynx as an important source of pathogens [21-23] may have contributed to gastric and tracheal colonization in all three studies. Treatment with $\mathbf{H}_{2}$ receptor blockers or antacids may predispose to pneumonia in intubated patients $[7,11,12]$, but the

Table 5. Results of coagulation studies over time in the study population.

\begin{tabular}{|c|c|c|c|}
\hline \multirow{2}{*}{$\begin{array}{l}\text { Day of } \\
\text { sample, } \\
\text { no. patients }\end{array}$} & DIC score* & $\%$ AT-111 ${ }^{\dagger}$ & $\% \mathrm{PK}^{\dagger}$ \\
\hline & $\begin{array}{c}\text { Mean } \pm \text { SD } \\
\text { (range) }\end{array}$ & $\begin{array}{c}\text { Mean } \pm \text { SD } \\
\text { (range) }\end{array}$ & $\begin{array}{l}\text { Mean } \pm \text { SD } \\
\text { (range) }\end{array}$ \\
\hline Day 1,40 & $4.2 \pm 1.86(1-8)$ & $83 \pm 13(59-117)$ & $73 \pm 16(42-120)$ \\
\hline Day 3,40 & $3.2 \pm 1.86(1-6)$ & $92 \pm 15(68-127)$ & $64 \pm 14(31-95)$ \\
\hline Day 5,39 & $3.2 \pm 1.43(0-7)$ & $100 \pm 17(50-139)$ & $59 \pm 15(36-97)$ \\
\hline Day 7,28 & $3.1 \pm 1.12(1-6)$ & $103 \pm 16(67-125)$ & $59 \pm 15(26-95)$ \\
\hline
\end{tabular}

NOTE. DIC $=$ disseminated intravascular coagulation, AT-III $=$ antithrombin III, $\mathrm{PK}=$ prekallikrein.

* DIC score as defined [16], ranging from 0 to $13 ; 13=$ most severe DIC.

$\dagger$ Normal values [16]: AT-IIl $80 \%-120 \%$, PK $75 \%-125 \%$. 
significance of gastric colonization as a source of the pathogens causing pneumonia needs to be further defined.

The difference between our data and results from previous studies may be partly related to characteristics of our patient population. We studied exclusively neurosurgical ICU patients who did not require abdominal surgery. Most trials were conducted among patients with various underlying diseases and included also patients with abdominal surgery [5, $8,10]$ and paralytic ileus [10]. The median age in our patient population was $34 \mathrm{y}$, whereas patients in previous studies had mean ages from 47 to 65 y $[5,9$, 10]. Differences in these factors could have affected gastric colonization [26] and may have reduced the risk of subsequent tracheal colonization among our patients.

In our series, the rate of nosocomial pneumonia during the first week of mechanical ventilation was $37.5 \%$, which is in the range of other studies that reported rates of $21 \%-52 \%[5,8,11]$. The pathogens most frequently associated with pneumonia were $H$. influenzae, $S$. aureus, and Str. pneumoniae. Nosocomial pneumonia is commonly caused by gram-negative bacilli [27], but a high incidence of $S$. aureus pneumonia in neurosurgical patients receiving mechanical ventilation has previously been described [21, 28].

In our study, the rate of nosocomial septicemia was $12.5 \%$. Four of five cases were caused by $S$. aureus, the organisms responsible for $\sim 20 \%$ of endemic hospital-acquired bacteremias $[29,30]$. In a large study of surgical ICU patients, bacteremia was identified in $14.4 \%$ [25]. In that study, an additional $13 \%$ of patients developed "nonbacteremic sepsis," that is a clinical picture of sepsis without positive blood cultures. High gastric bacterial counts might be a source for endotoxin or other microbial components in the blood and could explain the condition of nonbacteremic clinical sepsis [4]. Our data do not support the hypothesis that gastric microbial colonization results in endotoxemia, coagulation activation, or septicemia in ICU patients without gastric surgery.

In conclusion, gastric microbial growth is common in ICU patients with high gastric pH. However, the role of gastric colonization in the occurrence of nosocomial infections has not yet been clearly defined. The results of our study indicate that the colonized stomach is not an important source of noso- comial infections or endotoxemia in neurosurgical ICU patients receiving mechanical ventilation.

\section{References}

1. Peura D. Stress-related mucosal damage: an overview. Am J Med 1987;83(Suppl 6A):3-7

2. Shuman RB, Schuster DP, Zuckerman GR. Prophylactic therapy for stress ulcer bleeding: a reappraisal. Ann Intern Med 1987;106:562-567

3. Ruddell WSJ, Axon ATR, Findlay JM, Bartholomew BA, Hill MJ. Effect of cimetidine on the gastric bacterial flora. Lancet 1980;1:672-674

4. Hillman KM, Riordan T, O'Farrell SM, Tabaqchali S. Colonization of the gastric contents in critically ill patients. Crit Care Med 1982;10:444-447

5. du Moulin GC, Paterson DG, Hedley-Whyte J, Lisbon A. Aspiration of gastric bacteria in antacid-treated patients: a frequent cause of postoperative colonisation of the airway. Lancet 1982;1:242-245

6. Boero M, Pera A, Andriulli A, Ponti V, Canepa G, Palmas F, Duglio A, Molinaro GC, Toselli M, Riccardino N. Candida overgrowth in gastric juice of peptic ulcer subjects on short- and long-term treatment with $\mathrm{H}_{2}$-receptor antagonists. Digestion 1983;28:158-163

7. Driks MR, Craven DE, Celli BR, Manning M, Burke RA, Garvin GM, Kunches LM, Farber HW, Wedel SA, McCabe WR. Nosocomial pneumonia in intubated patients given sucralfate as compared with antacids or histamine type 2 blockers: the role of gastric colonization. N Engl J Med 1987;317:1376-1382

8. Daschner F, Kappstein I, Engels I, Reuschenbach K, Pfisterer J, Krieg N. Vogel W. Stress ulcer prophylaxis and ventilation pneumonia: prevention by antibacterial cytoprotective agents? Infect Control Hosp Epidemiol 1988;9:59-65

9. Pingleton SK, Hinthorn DR, Liu C. Enteral nutrition in patients receiving mechanical ventilation: multiple sources of tracheal colonization include the stomach. Am J Med 1986;80:827-832

10. Atherton ST, White DJ. Stomach as source of bacteria colonising respiratory tract during artifical ventilation. Lancet 1978;2:968-969

11. Craven DE, Kunches LM, Kilinsky V, Lichtenberg DA, Make BJ, McCabe WR. Risk factors for pneumonia and fatality in patients receiving continuous mechanical ventilation. Am Rev Respir Dis 1986;133:792-796

12. Tryba M. Risk of acute stress bleeding and nosocomial pneumonia in ventilated intensive care unit patients: sucralfate versus antacids. Am J Med 1987;83(Suppl 3B):117-124

13. Reusser P, Gyr K, Scheidegger D, Buchmann B, Buser $M$, Zimmerli W. A randomized, controlled, endoscopic study of ranitidine and antacids for the prevention of gastroduodenal stress lesions and bleeding in critically ill patients [abstract]. Gastroenterology 1988;94(Suppl):A373

14. Jones RN, Barry AL, Gavan TL, Washington JA. Susceptibility tests: microdilution and macrodilution broth procedures. In: Lennette EH, Balows A, Hausler WJ, Shadomy HJ, eds. Manual of clinical microbiology, 4th ed. Washington, DC: American Society for Microbiology, 1985:972-977 
15. Harris RI, Stone PCW, Stuart J. An improved chromogenic substrate endotoxin assay for clinical use. J Clin Pathol 1983;36:1145-1149

16. Lämmle B, Tran TH, Ritz R, Duckert F. Plasma prekallikrein, factor XII, antithrombin III, $C_{1}$-inhibitor and $\boldsymbol{\alpha}_{2}$-macroglobulin in critically ill patients with suspected disseminated intravascular coagulation (DIC). Am J Clin Pathol 1984;82:396-404

17. Buser MW, Oberholzer M, Christen $H$, Heitz PU. Analysis of object clustering. Anal Quant Cytol Histol 1987;9: 303-314

18. Gray JDA, Shiner M. Influence of gastric $\mathrm{pH}$ on gastric and jejunal flora. Gut 1967;8:574-581

19. Drasar BS, Shiner M, McLeod GM. Studies on the intestinal flora. I. The bacterial flora of the gastrointestinal tract in healthy and achlorhydric persons. Gastroenterology 1969;56:71-79

20. Giannella RA, Broitman SA, Zamcheck N. Gastric acid barrier to ingested microorganisms in man: studies in vivo and in vitro. Gut 1972;13:251-256

21. Espersen F, Gabrielsen J. Pneumonia due to Staphylococcus aureus during mechanical ventilation. J Infect Dis 1981; 144:19-23
22. Sanderson PJ. The sources of pneumonia in ITU patients. Infect Control 1986;7(Suppl 2):104-106

23. Schwartz SN, Dowling JN, Benkovic C, DeQuittner-Buchanan M, Prostko T, Yee RB. Sources of gram-negative bacilli colonizing the tracheae of intubated patients. J Infect Dis 1978;138:227-231

24. Cross AL, Roup B. Role of respiratory assistance devices in endemic nosocomial pneumonia. Am J Med 1981;70: 681-685

25. Meakins JL, Wicklund B, Forse RA, McLean APH. The surgical intensive care unit: current concepts in infection. Surg Clin North Am 1980;60:117-132

26. Simon GL, Gorbach SL. Intestinal flora in health and disease. Gastroenterology 1984;86:174-193

27. Hessen MT, Kaye D. Nosocomial pneumonia. Crit Care Clin 1988;4:245-257

28. Braun SR, Levin AB, Clark KL. Role of corticosteroids in the development of pneumonia in mechanically ventilated head-trauma victims. Crit Care Med 1986;14:198-201

29. Maki DG. Nosocomial bacteremia: an epidemiologic overview. Am J Med 1981;70:719-732

30. Eykyn SJ. Staphylococcal sepsis: the changing pattern of disease and therapy. Lancet 1988;1:100-104 